\title{
Magnitude of Cenozoic erosion from mean sonic transit time, offshore Taiwan
}

\author{
Shi-Chie Fuh \\ Exploration and Development Research Institute, Chinese Petroleum Corporation, P.O. Box 166, Miaoli, Taiwan
}

Received 8 September 1999; received in revised form 29 June 2000; accepted 4 July 2000

\begin{abstract}
Mean sonic transit times from eight stratigraphic units in forty-four wells in western and northern offshore Taiwan were plotted against depth. Apparent erosion (displacement on the depth axis from the normal compaction) was determined for each unit in each well. Cretaceous and Eocene units show greater apparent erosion than Miocene and Pliocene units in the same well, which in turn show more erosion than Pleistocene units. Apparent erosions derived from two different units are plotted against each other for correlation analysis. Based on the analysis, the main periods of erosion were during the Oligocene and Plio-Pleistocene.

The timing of erosion inferred from sonic interval transit is consistent with recognized unconformities, and its areal distribution is consistent with the observed structural evolution of the region. The maximum true erosion (corrected for post-erosion burial) at the Oligocene unconformity was $3500 \mathrm{~m}$ on the Penghu Platform. Approximately $2500 \mathrm{~m}$ of true erosion occurred on the Kuanin Ulift and the Pengchiahsu Platform. Due to moderate-to-minor erosion and a great amount of post-erosion burial, true magnitude of erosion is masked at the Miocene unconformity in most of the area.

Erosion of up to $500 \mathrm{~m}$ on the eastern side of the Penghu Island at the Pleistocene unconformity defines the shape of the present-day Penghu Waterway. In the northern offshore area up to $1000 \mathrm{~m}$ of Plio/Pleistocene, true erosion occurred in the Taiwan-Sinzi folded zone where Miocene folds are observed. The magnitude of true erosion decreased west of the Taiwan-Sinzi folded zone to $500 \mathrm{~m}$ in the Pengchiahsu Basin. A maximum of $500 \mathrm{~m}$ of true erosion is also observed in the west offshore area along Hsing-Chu to Miaoli coast. (C) 2000 Elsevier Science Ltd. All rights reserved.
\end{abstract}

Keywords: Cenozoic erosion; Mean sonic time; Offshore Taiwan

\section{Introduction}

Burial history and paleo-thermal gradient are two of several important factors for sedimentary basin and petroleum system modeling (Waples, 1994). The distribution of oil windows through geological time gained from modeling depends tremendously upon the two input factors. Yet their determinations are usually highly uncertain, resulting in an outcome of generally of low confidence. True erosion at an unconformity is crucial for the determination of the burial history once the age of strata is determined. Hu, Chou, Yuan, Lin, and Chi (1981) estimated locally, using a few sonic and gamma logs, the magnitude of erosion at the Oligocene unconformity in Peikang-Wangkung and Western Taiwan foothill area. Other works conducted previously by the CPC staff are all single well based. The areal distribution of erosion for the regional unconformity in the offshore Taiwan area has not been consistently mapped and understood. Although by adjusting the paleo-thermal gradient in basin modeling, the quantity of erosion analysis can fit approximately to the present-day kerogen maturation profile, which is analyzed from cuttings or core samples. Yet, the resultant erosion and paleo-thermal gradient may not be consistent with the paleo-tectonic mechanism shown in the map. The objective of this study is to analyze the true magnitude of erosion, consistent in the sense of paleo-structure, at regional Cenozoic unconformities in offshore Taiwan areas. It will serve as a database to assist the further basin modeling of petroleum systems.

Quite often, sonic, gamma ray and kerogen maturation profiles show a remarkable difference above and below an unconformity and are offset right at the unconformity. The magnitude of erosion at unconformity for a single well has been discussed in previous studies. It has been resolved through projecting upward the trend in older strata underneath the unconformity to match the log values in younger strata above the unconformity (Dow, 1977; Hu et al., 1981; Magara, 1976). Depth shift on shale transit time curve of uplifted and over-compacted strata to match that of the normally compacted shale has also been applied to estimate 


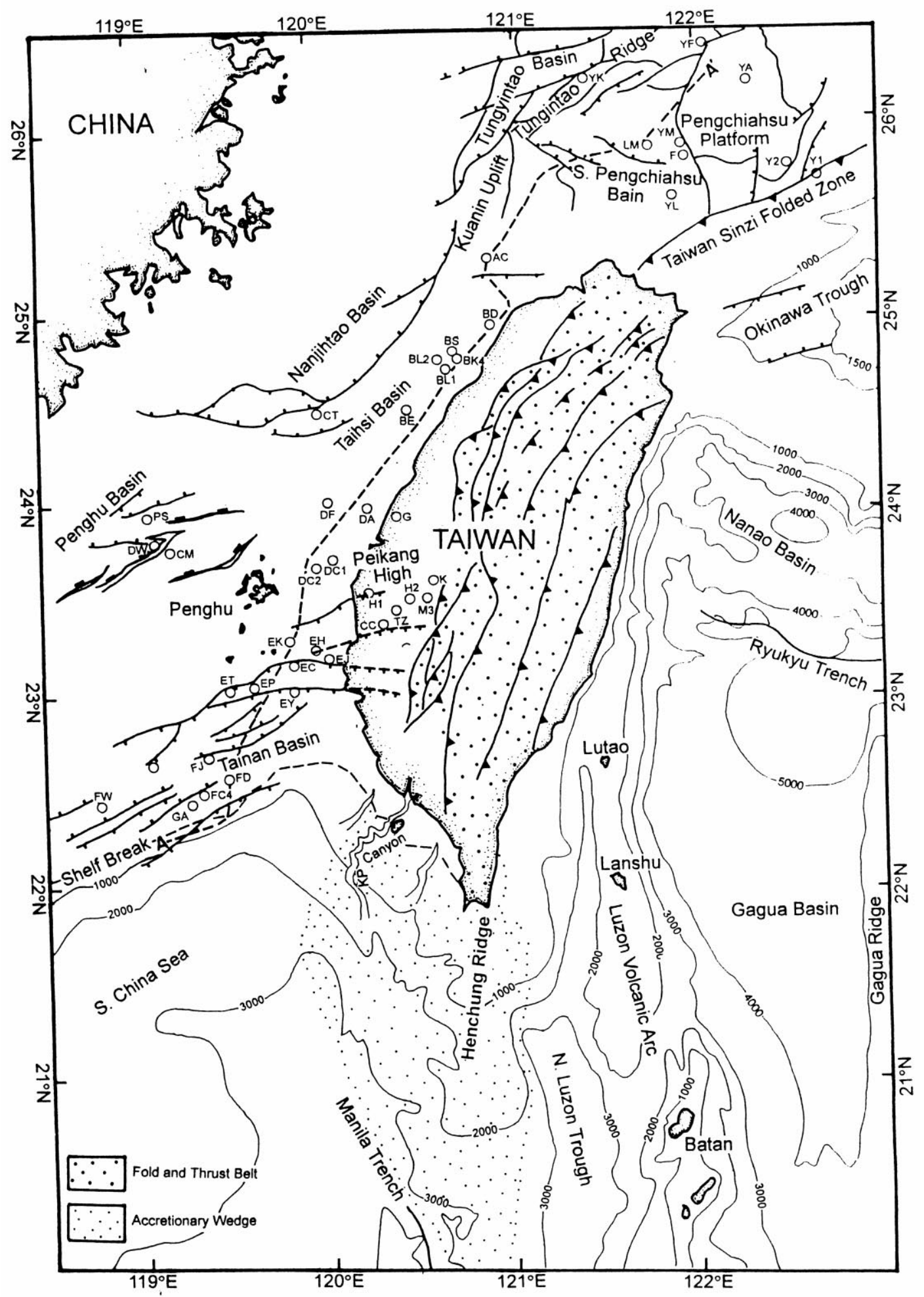

Fig. 1. Tectonic frame works in the study area and well locations.

the relative erosion. To apply this method, a regional normal compaction curve for shale has to be established first. The presence of abnormal lithological succession (coal-rich zone, volcanic rock, organic-rich zone, overpressure zone etc.) around the unconformity and sparse sampling of kero- gen maturation analysis can easily bias estimation of erosion magnitude. These techniques resolve only apparent erosion, which is strongly related to post-erosion burial and can be easily masked. Post-erosion burial correction was also discussed and applied to apparent erosion in previous 


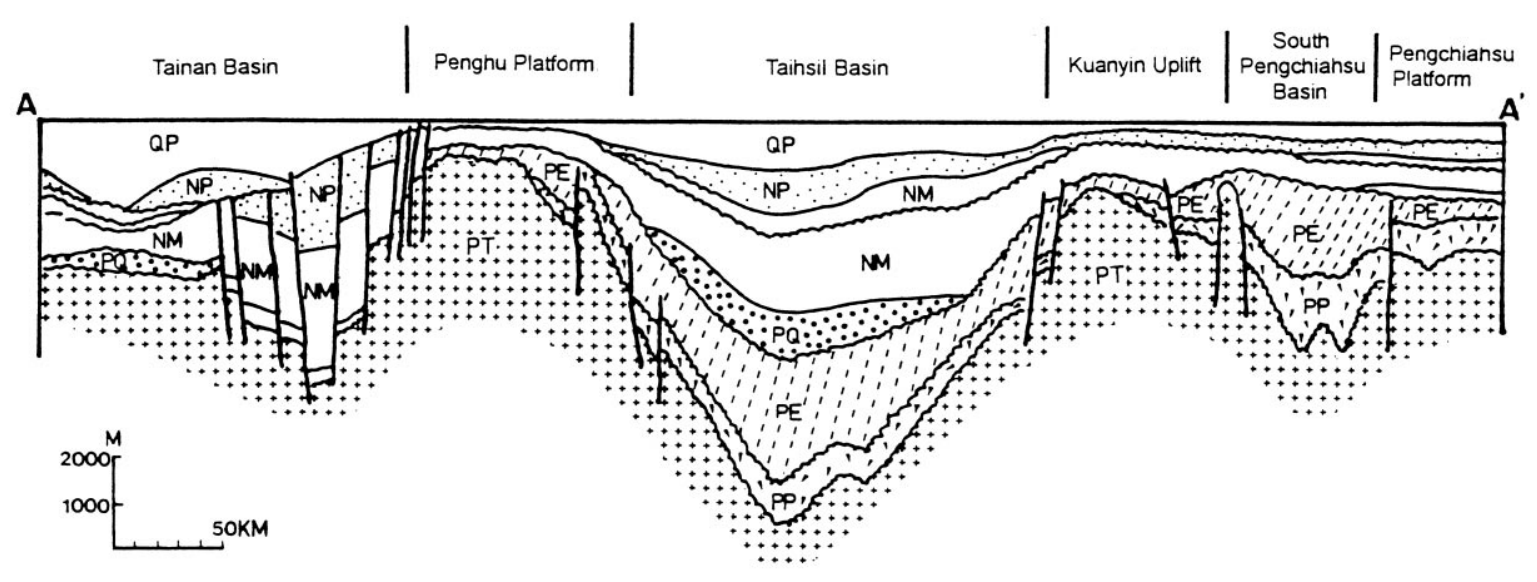

Fig. 2. NE-SW cross section interpreted from seismic section demonstrates the major tectonic units in the study area (after Sun, 1982). QP, Pleistocene; NP, Pliocene; NM, Miocene; PO, Oligocene; PE, Eocene; PP, Paleocene; PT, Pre-Tertiary.

studies (Hillis, 1993; 1995; Japsen, 1998; Katz, Pheifar \& Schunk, 1988; Menpes \& Hillis, 1995). In contrast to the single-well approach, mean sonic transit times of some selected stratigraphic units from all wells in a wide region are cross-plotted with midpoint depths of the unit. Therefore, a normal compaction curve and apparent erosion can thus be obtained at the same time.

\section{Tectonic background}

The study area covers western on/offshore and northern offshore areas of Taiwan (Fig. 1). The main geologic features in the study area include several Tertiary rift basins (Sun, 1985). The rift phase of these basins were mainly initiated in Paleogene time, followed by a post-rift subsidence phase in the Neogene. A Post-Oligocene unconformity, which is widely spread throughout the offshore Taiwan area, separates these two phases. In the northern part of the study area, the main tectonic elements include the following: the Pengchiahsu Platform, the Pengchiahsu Basin, the Tungyintao Ridge, and the Kuanin Uplift with the Nanjihtao Basin and the Taihsi Basin in the center. In the southern part, the Penghu Basin in the north and the Tainan Basin in the south are separated by paleo-highs trending NE-SW (i.e. the Penghu Platform and the Peikang-Wangkung paleo-ridge). To determine the quantity of erosion at unconformity from sonic logs, a total of forty-four wells located at and around these structural units were selected. The northeastern flank of the study area is located in the northern part of a convergent belt, the Taiwan-Sinzi folded zone (Lee, Shor, Bibee, Lu \& Hilde, 1980; Letouzey \& Kimura, 1985). Letouzey and Kimura suggested that, after a change in the motion of Philippine Plate with respect to Eurasia Plate during early Miocene, general uplift and faulting occurred and formed the Taiwan-Sinzi folded zone. The uplift ended in middle or late Miocene. A wide spread PlioPleistocene unconformity exists in this area (Hsiao, 1997).
The central part of this convergent belt lays the Taiwan fold and thrust belt. Further south, a transitional zone from Luzon subduction system to an arc-continent collision belt is represented by a series of tectonic features including the Manila Trench, the Henchung Ridge, the North Luzon Trough, and the Luzon Arc (Huang \& Yin, 1990; Huang, Shyu, Lin, Lee \& Sheu, 1992; Liu, Huang \& Teng, 1997). Continuing up to Quaternary, the Plio-Pleistocene arc-continent collision (Lu \& Hsu, 1992; Suppe, 1984; Teng, 1990) initiated loading of the Taiwan mountain-belt thrust wedge and flexural bending of surrounding Tertiary basin basements. This tectonic event also brought tremendous amounts of sediment into the surrounding Tertiary basin lows (Lee, Tang \& Ting, 1993). Fig. 2 is a NE-SW cross section (Sun, 1982) extending from the northern-most Pengchiahsu Platform to the southern-most Tainan Basin (location see Fig. 1).

\section{Apparent/true erosion estimation methodology and procedures}

Since depth-controlled compaction is largely irreversible, units that have been uplifted to a shallower burial depth should be overcompacted with respect to their present burial-depth (Hillis, 1991; Hillis, Thomson \& Underhill, 1994; Issler, 1992; Magara, 1976). It is assumed that all units following a normal compaction history with burial cannot be reversed by subsequent exhumation or erosion. A vertically and laterally consistent relationship between velocity and depth is required for the determination of the apparent erosion of the stratigraphic-equivalent units. Shale, therefore, has been widely used because it is believed to be the one to possess the most simple velocity/depth relationship. Ideally, reasonably thick units are favored because they are less vulnerable to lateral variation in sedimentological or diagenetic phenomena that might induce deviations in the assumed normal velocity/depth relationship. 
(a) Well A

Well B

Well C

Normal Compaction

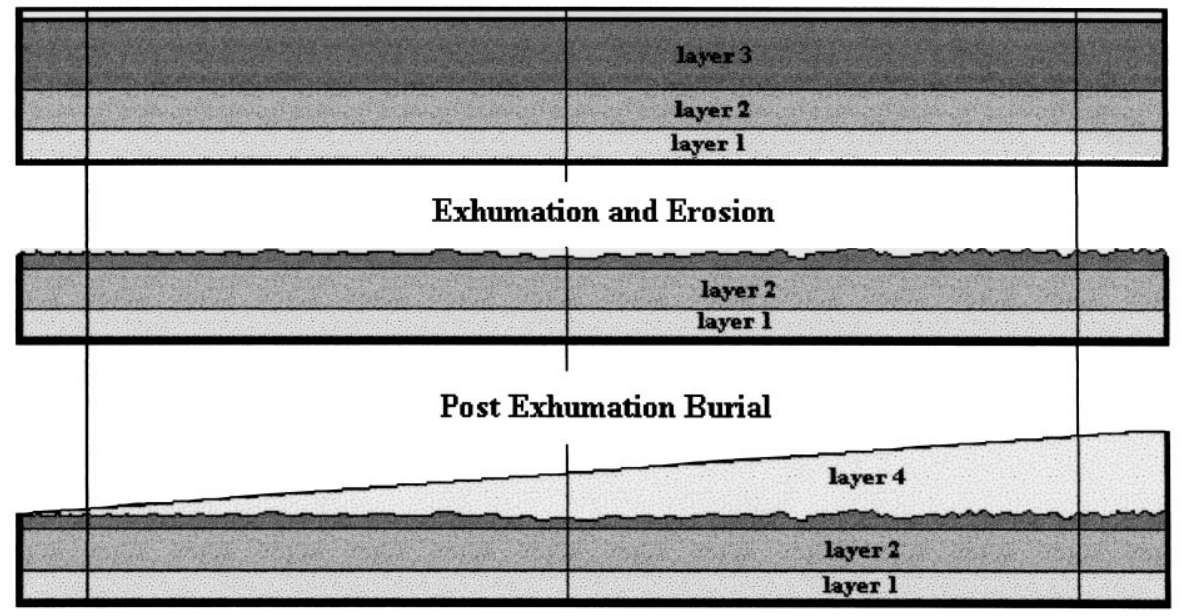

(b) Sonic $\log \mathrm{A}$

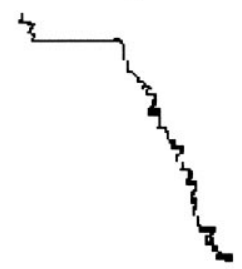

Sonic $\log B$

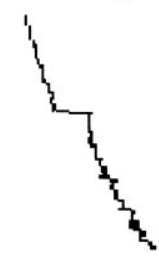

Sonic Log C

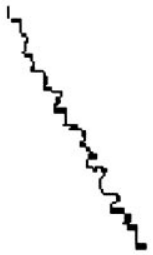

(c)

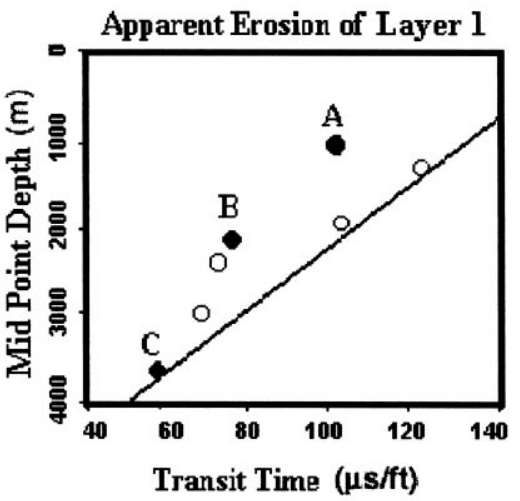

Fig. 3. Schematic diagrams for the methodology applied in the study. (a) A geological model showing the same amount of eroded rocks at the time erosion event occurred were reburied by different scale of post-erosion sedimentation at three well locations. (b) Offset of sonic log observed at the unconformity is decreased with the increasing post-erosion burial. (c) Apparent erosion estimation on the mid-point depth vs. mean sonic transit time plot.

Furthermore, units should not exhibit any overpressure or hydrocarbon-filled porosity. Coals, strata rich in organic matter and volcanic rocks, of which sonic velocities are abnormally low or high, should also be avoided. The procedures for the apparent erosion determination at a regional unconformity are as follows.

\subsection{Mean sonic transit time vs. mid-point depth plot}

The top and bottom of a stratum are interpreted through well $\log$ correlation and microfossil dating. Midpoint burialdepth is calculated from seafloor or outcrop. Mean sonic transit time of the unit is cross-plotted against midpoint burial-depth (Fig. 3c).

\subsection{Regional normal compaction curve determination}

A critical factor in determining the magnitude of apparent erosion is the selection of the normal compaction curve. It can be determined in two ways using mean sonic transit time vs. midpoint depth plot: (a) for a linear increase in velocity with depth, define the normal compaction line by linking two reference wells so that no points fall on to its right side, as shown in Fig. 3c; (b) for a consistent velocity-depth relationship between wells, mean intra-well 

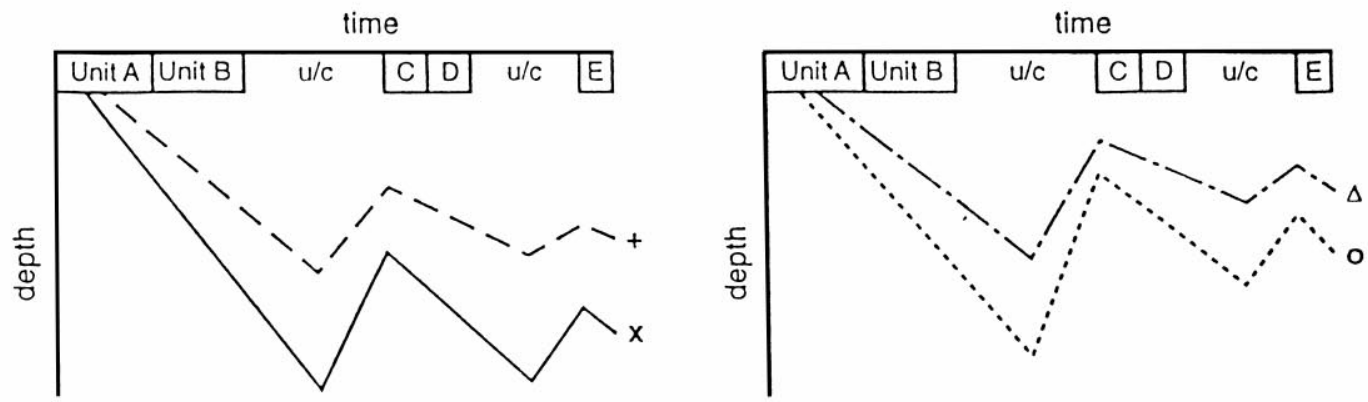

(a)
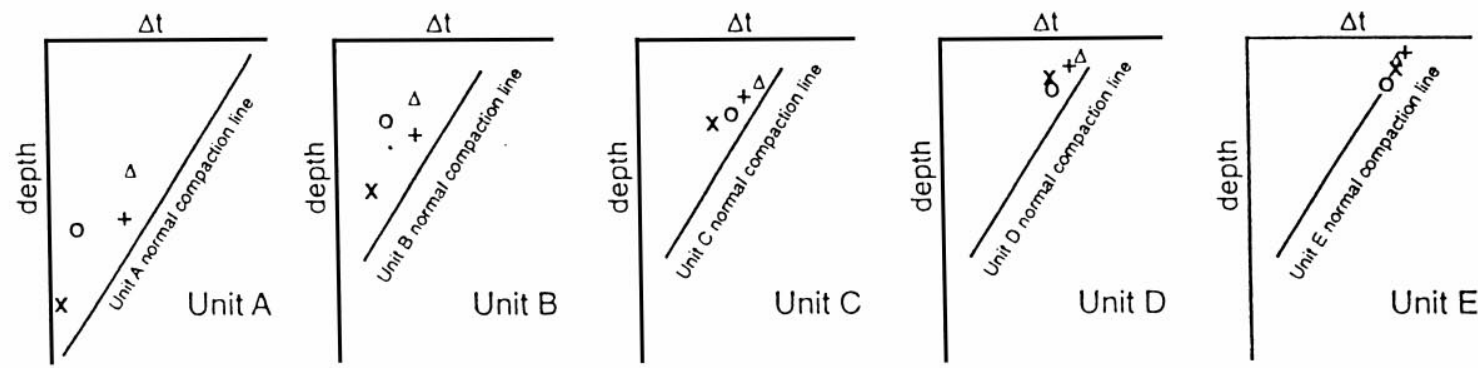

(b)
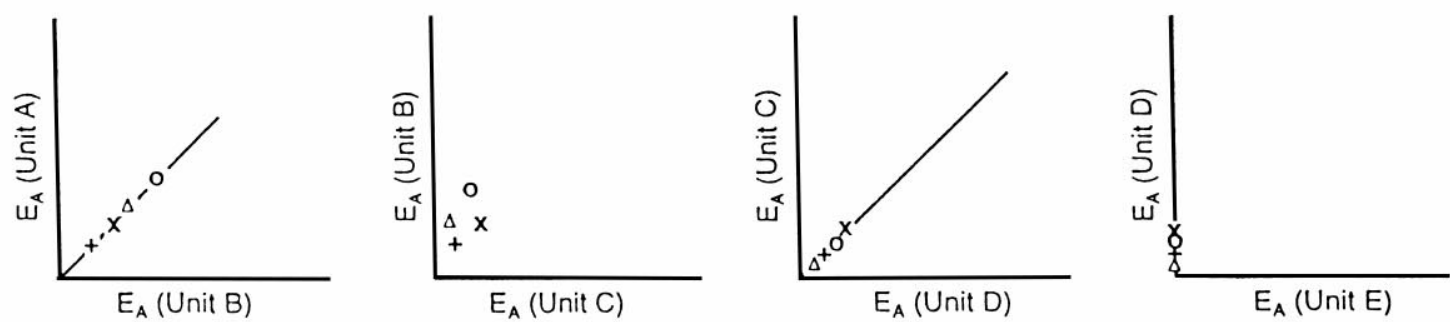

(c)

Fig. 4. (a) Theoretical burial history plot for four wells in a basin which has undergone two distinct exhumation events, both followed by further burial. All wells in the basin have similar histories, with slightly different magnitudes of exhumation and burial. (b) $\times,+, \bigcirc$, and $\Delta$ are the $\Delta t \mathrm{~s}$ in the given unit for different wells in the basin. (c) Units A and B yield the same apparent exhumation values, as do Units C and D. Unit B exhibits greater apparent exhumation than Unit C, and Unit D exhibits greater apparent exhumation than Unit E, which is normally compacted and exhibits no exhumation (after Menpes, 1997).

velocity/depth gradient within a unit can be combined with a single well with the lowest velocity for its depth to determine the normal compaction curve (Hillis, 1991, 1993; Hillis et al., 1994).

\subsection{Apparent erosion calculation}

The magnitude of apparent erosion

$E_{\mathrm{A}}=1 / m\left(\Delta t_{u}-\Delta t_{0}\right)-d_{u}$ where $m$ is the slope of normal compaction line determined in Fig. 3c, $\Delta t_{u}$ the mean interval sonic transit time of the well that is considered, $\Delta t_{0}$ the surface intercept of the normal compaction line and $d_{u}$ the depth of midpoint of stratigraphic unit taken from seafloor or ground surface.

\subsection{Apparent erosion correlation analysis}

Apparent amounts of erosions resolved from different units are plotted against each other to verify their 


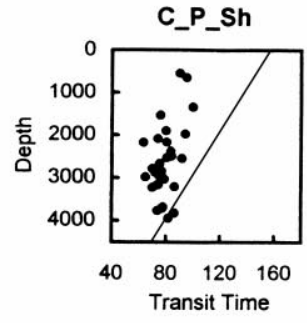

LoEoc_A_Sh

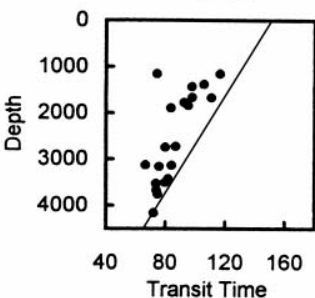

S_LoMio

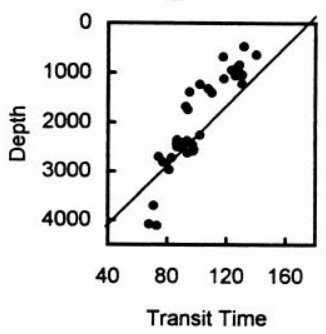

S_UpMio

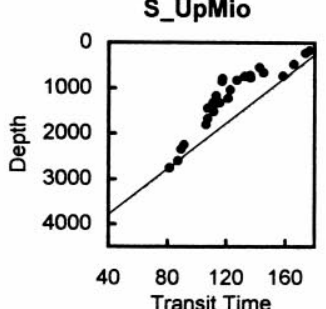

LoPlio_A_Sh

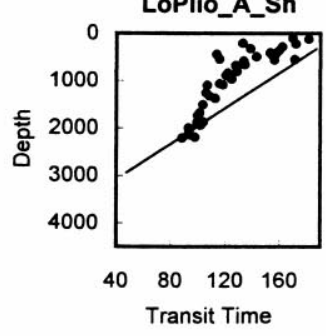

C_A_Sh

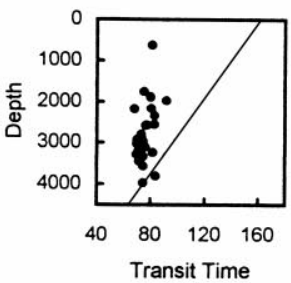

MidEoc_P_Sh

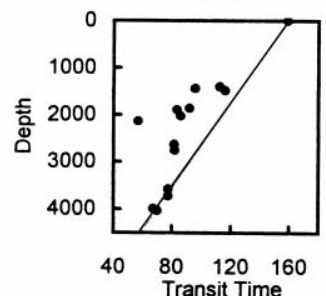

LoMio_A_Sh

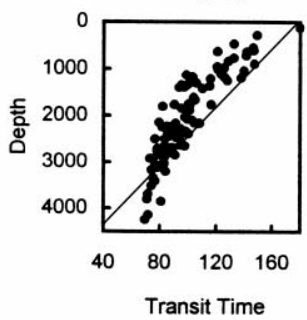

UpMio_A_Sh
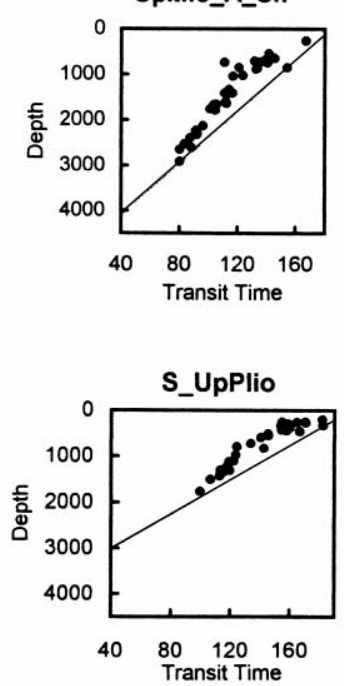

C_A_Sa

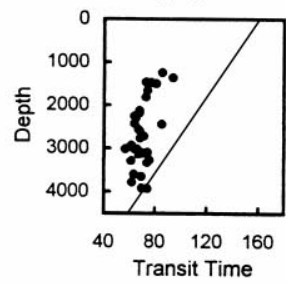

MidEoc_A_Sh

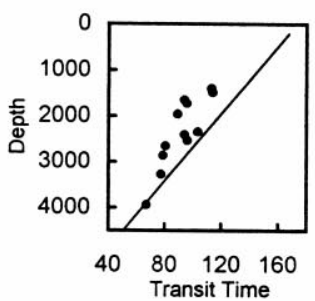

LoMio_A_Sa

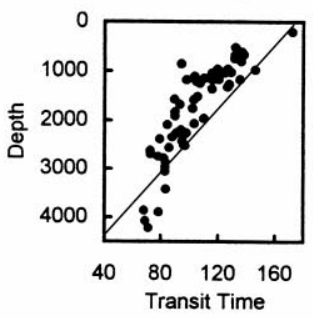

UpMio_A_Sa
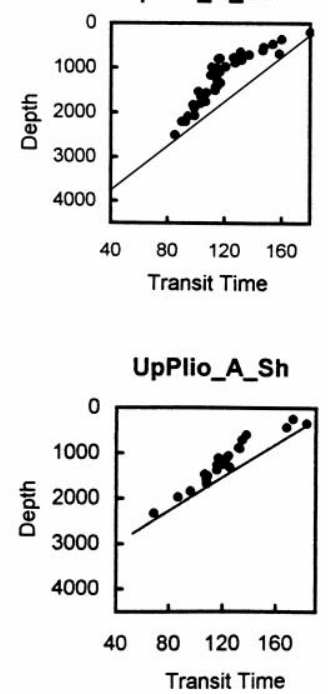
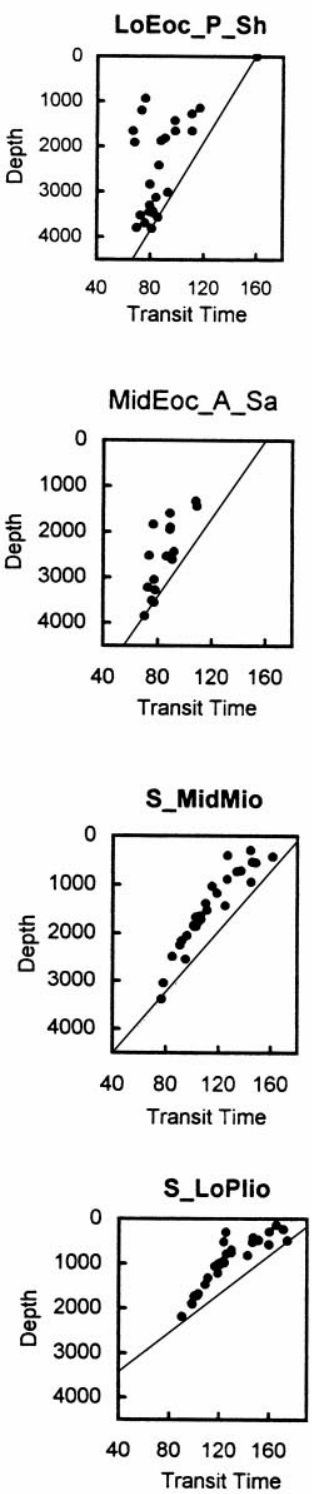

MidEoc_A_Sa

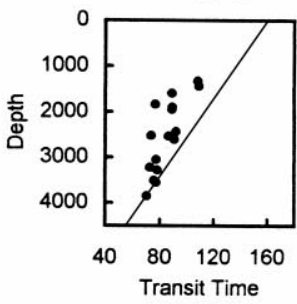

S_MidMio
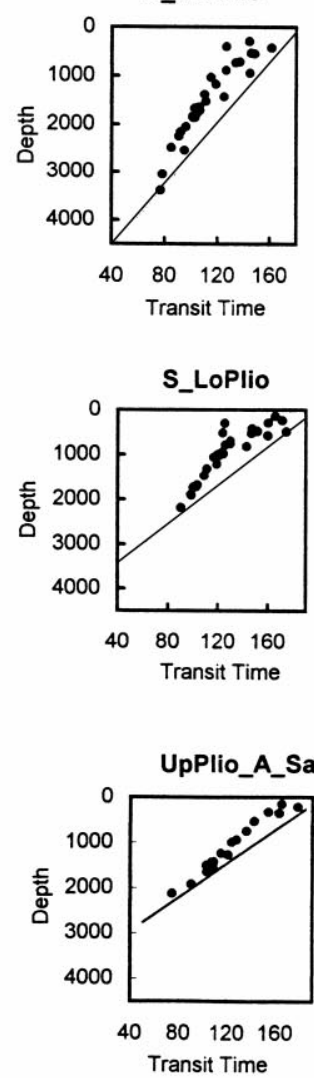

Fig. 5. Mean transit-time vs. depth plots of units defined for the eight selected strata. Straight lines on plots are normal compaction lines. Points above the normal compaction line represent overcompacted strata experienced uplifting and those bellow the line represent undercompacted strata enriched in organic matter. (C, Cretaceous; LoEoc, Lower Eocene; MidEoc, Middle Eocene; LoMio, lower Miocene; MidMio, Middle Miocene; UpMio, Upper Miocene; LoPlio, Lower Pliocene; UpPlio, Upper Pliocene; S_, whole-strata-based; A_Sh, averaged-shale unit; A_Sa, averaged sand unit; P_Sh, pure-shale unit.)

consistency. A high correlation coefficient is reflected in a concentration of data along the plot diagonal. In an area where more than one regional unconformity exists, this correlation analysis is important not only for verification of consistency but also for differentiation. Menpes (1997) has demonstrated this method of differentiation for an unconformity through a theoretical burial history correlation (Fig. 4). Apparent erosion analyzed from two units may 
Table 1

Apparent erosions resolved for all Plio-Pleistocene units. (S_LoPlio: Strata based Lower Pliocene; S_UpPlio: Strata based Upper Pliocene; S_Plei: Strata based Pleistocene; LoPlio_A_Sa: Lower Pliocene averaged sand; LoPlio_A_Sh: Lower Pliocene averaged shale; UpPlio_A_Sa: Upper Pliocene averaged sand; UpPlio_A_Sh: Upper Pliocene averaged shale)

\begin{tabular}{|c|c|c|c|c|c|c|c|}
\hline Well name & S_LoPlio & S_UpPlio & LoPlio_A_Sa & UpPlio_A_Sa & UpPlio_A_Sh & LoPlio_A_Sh & S_Plei \\
\hline YF & 500 & 299 & 371 & 206 & 336 & 483 & -24.8 \\
\hline YA & 10.8 & 18.3 & & & 41 & 1.6 & \\
\hline YK & 330 & 322 & 385 & & & 250 & \\
\hline YM & 505 & 495 & & & & 460 & \\
\hline Y2 & 1045 & 616 & 801 & & & 1118 & \\
\hline Y1 & 1226 & & 987 & & & 1315 & \\
\hline YL & 221 & 392 & & & & 335 & \\
\hline $\mathrm{F}$ & 570 & 418 & 611 & & & 441 & \\
\hline LM & 555 & 446 & 408 & & & 629 & \\
\hline \multicolumn{8}{|l|}{$\mathrm{AC}$} \\
\hline BL1 & & & 618 & & & 835 & \\
\hline BL2 & 632 & 542 & & & & & \\
\hline $\mathrm{BE}$ & 653 & 645 & & & & 738 & \\
\hline BS & 593 & 480 & & & & 634 & 83 \\
\hline BD & 707 & 542 & & 384 & 603 & & \\
\hline BK4 & 609 & 182 & & & & & \\
\hline $\mathrm{CT}$ & & & 218 & & & & \\
\hline $\mathrm{DF}$ & & & 279 & & & & \\
\hline DA & & 416 & & & & & 40 \\
\hline DC1 & & 538 & & 423 & & & 103 \\
\hline DC2 & & & & 373 & & & \\
\hline \multicolumn{8}{|l|}{ DW } \\
\hline \multicolumn{8}{|l|}{$\mathrm{CM}$} \\
\hline \multicolumn{8}{|l|}{ PS } \\
\hline EP & 740 & 476 & 633 & & & 823 & 48 \\
\hline EJ & 322 & 382 & 269 & 363 & 458 & 434 & \\
\hline ET & 651 & 157 & 488 & 37 & & 478 & \\
\hline $\mathrm{EH}$ & 739 & 527 & & & 662 & 861 & \\
\hline EY & 330 & 380 & 262 & 365 & 450 & 451 & 32 \\
\hline $\mathrm{EC}$ & 680 & 363 & & 468 & 246 & 774 & \\
\hline EK & 541 & & & & & 478 & \\
\hline $\mathrm{FC} 4$ & & 217 & & & & & \\
\hline FC6 & & 222 & & 273 & 345 & & \\
\hline GA & 189 & & & & 302 & 208 & 1.5 \\
\hline FD & & & & & 271 & 191 & \\
\hline $\mathrm{CC}$ & 454 & 347 & & 180 & 179 & & \\
\hline G & 209 & 263 & 145 & & & 311 & \\
\hline $\mathrm{TZ}$ & 517 & & 303 & & & 428 & \\
\hline K & 82.8 & 134 & 69 & & & 226 & \\
\hline H1 & 340 & 269 & 277 & & & & \\
\hline H3 & & & & 319 & 267 & & \\
\hline $\mathrm{H} 2$ & 403 & 268 & & 230 & 289 & & \\
\hline $\mathrm{FW}$ & 286 & 345 & & & & 488 & 46 \\
\hline FJ & 182 & 250 & & 331 & 407 & 432 & \\
\hline
\end{tabular}

have been originated from different unconformities if the correlation coefficient is low. In case of tremendous posterosion burial of the older unconformity, apparent erosion resolved from the unit underlying the older unconformity may represent the relative amount of eroded rocks for the younger unconformity. The current burial-depth of the older unconformity is resolved as an upper limit of true erosion of the older unconformity.

\subsection{Post-erosion burial correction}

The magnitude of apparent erosion, reflected by the offset of a sonic log at an unconformity, decreases with increasing post-erosion burial of the unconformity. It will be masked once the subsequent post-erosion burial exceeds the true magnitude of erosion at that unconformity (Fig. 3a and b). Apparent erosion has to be corrected for post-erosion burial to resolve the true erosion at the end of denudation as follows: (a) if the offset can still be observed in sonic log at an unconformity, the total amount of eroded rocks $\left(E_{\mathrm{T}}\right)$ is equal to the sum of the resultant apparent erosion and the current burial-depth of the unconformity; (b) if the sonic log appears to be continuous without any offset at the unconformity, the true magnitude of erosion is masked and any value 
Table 2

Apparent erosions resolved for all Miocene units. (S_LoMio: Strata based Lower Miocene; S_MidMio: Strata based Middle Miocene; S_UpMio: Strata based Upper Miocene; LoMio_A_Sa: Lower Miocene averaged sand; LoMio_A_Sh: Lower Miocene averaged shale; UpMio_A_Sa: Upper Miocene averaged sand; UpMio_A_Sh: upper Miocene averaged shale)

\begin{tabular}{|c|c|c|c|c|c|c|c|}
\hline Well name & S_LoMio & S_MidMio & LoMio_A_Sa & LoMio_A_Sh & S_UpMio & UpMio_A_Sa & UpMio_A_Sh \\
\hline YF & 449 & & 388 & 773 & 503 & 472 & 448 \\
\hline YA & 132 & & 39.5 & 215 & 104 & 112 & 0.3 \\
\hline FK & & & & & 611 & 559 & 491 \\
\hline YM & 678 & 841 & 544 & 876 & 685 & 533 & 671 \\
\hline $\mathrm{Y} 2$ & 1076 & & 1000 & 1064 & 1010 & 1026 & 1146 \\
\hline $\mathrm{Y} 1$ & 1271 & 1132 & 858 & 1217 & 1070 & 1039 & 1115 \\
\hline YL & 693 & & 740 & 675 & 749 & 632 & 784 \\
\hline $\mathrm{F}$ & 1165 & 909 & 915 & 1276 & 676 & 615 & 640 \\
\hline LM & 452 & & & 556 & 680 & & \\
\hline $\mathrm{AC}$ & 341 & 267 & 725 & 606 & 51.5 & 57.8 & \\
\hline BL1 & & & & 213 & & 431 & \\
\hline BL2 & 417 & 804 & & & 670 & 557 & \\
\hline $\mathrm{BE}$ & 390 & 809 & & 302 & 503 & 488 & 393 \\
\hline BS & 473 & 896 & & 468 & 625 & 568 & 625 \\
\hline $\mathrm{BD}$ & 482 & 769 & & 614 & 582 & 452 & 485 \\
\hline BK & 540 & 731 & & & 636 & & \\
\hline CT & 565 & & 964 & 670 & 228 & 394 & 226 \\
\hline $\mathrm{DF}$ & 869 & 738 & & 897 & 178 & 827 & 588 \\
\hline DA & 147 & 412 & 585 & 154 & 543 & & \\
\hline DC1 & 583 & 551 & 844 & 483 & & & \\
\hline DC2 & 1133 & 1388 & 1974 & 1153 & & & \\
\hline DW & 663 & 649 & 533 & $274(416)^{\mathrm{a}}$ & 222 & & \\
\hline \multicolumn{8}{|l|}{$\mathrm{CM}$} \\
\hline \multicolumn{8}{|l|}{ PS } \\
\hline EP & 733 & 749 & 822 & 574 & 709 & 715 & 654 \\
\hline $\mathrm{EJ}$ & & 267 & & 596 & 272 & 352 & 353 \\
\hline ET & 962 & 945 & & & 790 & 845 & 612 \\
\hline $\mathrm{EH}$ & & 882 & & & 695 & 760 & 688 \\
\hline $\mathrm{EY}$ & $-145^{\mathrm{b}}$ & 300 & & $-174^{b}$ & 222 & 305 & 320 \\
\hline $\mathrm{EC}$ & 613 & 777 & 813 & 562 & 803 & 828 & 756 \\
\hline EK & 827 & 930 & 893 & 804 & & & \\
\hline $\mathrm{FC} 4$ & -5.5 & 738 & & & 443 & & \\
\hline GA & -24 & & 315 & 73 & & & \\
\hline FD & & & & 94 & & & 295 \\
\hline $\mathrm{CC}$ & 350 & 694 & 536 & 402 & & & 466 \\
\hline G & 124 & & 441 & 103 & & & \\
\hline $\mathrm{TZ}$ & & 734 & & 740 & & & \\
\hline $\mathrm{K}$ & 203 & 652 & 342 & 115 & & & \\
\hline H1 & 290 & 273 & 136 & 134 & & & \\
\hline \multicolumn{8}{|l|}{ H3 } \\
\hline $\mathrm{H} 2$ & 507 & 704 & 583 & 561 & & 208 & 373 \\
\hline FW & $-418^{\mathrm{b}}$ & 12 & $-177^{\mathrm{b}}$ & $-486^{b}$ & 2 & & 174 \\
\hline FJ & $-634^{\mathrm{b}}$ & 228 & $-250^{\mathrm{b}}$ & $-567^{b}$ & 23 & 122 & 262 \\
\hline
\end{tabular}

\footnotetext{
${ }^{a}$ Conflicting biostratagraphic age.
}

b Rich content of organic matter.

less than current burial-depth of this unconformity would likely be the true magnitude of true erosion. Interpolating between wells, of which the true magnitude of erosion is not masked, will be one way to estimate the magnitude of $E_{\mathrm{T}}$ in the latter case.

\section{Data analyzing procedures}

Following the methodology described above, forty-four sonic logs in and around Tertiary basins in offshore Taiwan area (Fig. 1 for well locations) are analyzed to determine the true erosion for the Cenozoic unconformities. Eight strata are selected in this analysis: Cretaceous, Lower Eocene, Middle Eocene, Lower Miocene, Middle Miocene, Upper Miocene, Lower Pliocene and Upper Pliocene. All of these strata are inter-bedded, laterally varied sand and shale sequences. The existence of any thick, homogeneous shale throughout the area was not found. To avoid influence of lateral variation on lithology, the unit was also divided into several shale and sand sub-portions (or sub-units). For each well, succession in a unit possessing higher than $65 \%$ 
Table 3

Apparent erosions resolved for all Paleogene units. (MidEoc_A_Sa: Middle Eocene averaged sand; MidEoc_A_Sh: Middle Eocene averaged shale; MidEoc_P_Sh: Middle Eocene pure shale; LoEoc_A_Sh: Lower Eocene averaged shale; LoEoc_P_Sh: Lower Eocene pure shale; C_A_Sa: Cretaceous averaged sand; C_A_Sh: Cretaceous averaged shale)

\begin{tabular}{|c|c|c|c|c|c|c|c|}
\hline Well name & MidEoc_A_Sa & MidEoc_A_Sh & MidEoc_P_Sh & LoEoc_A_Sh & LoEoc_P_Sh & C_A_Sa & C_A_Sh \\
\hline YF & 882 & & & & & & \\
\hline YA & & & & 714 & 691 & & \\
\hline YK & & & & 611 & 927 & 1985 & \\
\hline YM & & & & 1191 & 1423 & 1260 & 1345 \\
\hline Y2 & & & & & $609.8^{c}$ & & \\
\hline Y1 & & & & & & 988 & \\
\hline YL & 339 & 327 & & 329 & 417 & & \\
\hline $\mathrm{F}$ & 1108 & 1127 & & 908 & & 905 & \\
\hline LM & 732 & 701 & 523 & & & & \\
\hline $\mathrm{AC}$ & & & & & & 1748 & 1797 \\
\hline \multicolumn{8}{|l|}{ BL1 } \\
\hline BL2 & & & & 440 & 662 & & \\
\hline \multicolumn{8}{|l|}{$\mathrm{BE}$} \\
\hline BS & $53.7(515)^{\mathrm{a}}$ & & $12(565)^{\mathrm{a}}$ & & & & \\
\hline $\mathrm{BD}$ & $28.5(492)^{\mathrm{a}}$ & $340(592)^{\mathrm{a}}$ & $-69(477)^{a}$ & & & & \\
\hline BK4 & & $73(492)^{\mathrm{a}}$ & & & & & \\
\hline \multicolumn{8}{|l|}{ BK12 } \\
\hline CT & & & & 1092 & 1390 & 1919 & 2050 \\
\hline DF & 1069 & 1290 & 2353 & & & & \\
\hline DA & & & & 26.8 & & & \\
\hline \multicolumn{8}{|l|}{$\mathrm{DC} 1$} \\
\hline $\mathrm{DC} 2$ & & & & 2794 & 2846 & & \\
\hline DW & 500 & 793 & 710 & 226 & 369 & & \\
\hline $\mathrm{CM}$ & 1134 & 616 & 1144 & 1204 & 1115 & & \\
\hline PS & 1558 & 1299 & 1385 & 1574 & & & \\
\hline EP & & & & & & 1027 & 990 \\
\hline EJ & & & & & & 894 & 618 \\
\hline ET & & & & & & & 2183 \\
\hline \multicolumn{8}{|l|}{$\mathrm{EH}$} \\
\hline \multicolumn{8}{|l|}{ EY } \\
\hline $\mathrm{EC}$ & & & & & & 1175 & 1278 \\
\hline EK & & & & & & & 3012 \\
\hline \multicolumn{8}{|l|}{$\mathrm{FC} 4$} \\
\hline FC6 & & & & & & $-152^{\mathrm{b}}$ & $-99^{\mathrm{b}}$ \\
\hline GA & & & & & & 173 & $-29.6^{\mathrm{b}}$ \\
\hline FD & & & & & & & 361 \\
\hline $\mathrm{CC}$ & & & & & & $1471^{\mathrm{c}}$ & 1010 \\
\hline $\mathrm{G}$ & & & & 699 & & & \\
\hline $\mathrm{TZ}$ & & & & & & 1176 & 1077 \\
\hline K & & & & & & 560 & 750 \\
\hline H1 & & & & & & 1904 & 1599 \\
\hline \multicolumn{8}{|l|}{ M3 } \\
\hline $\mathrm{H} 2$ & & & & & & & 1074 \\
\hline
\end{tabular}

\footnotetext{
a Conflicting biostratagraphic age.

${ }^{\mathrm{b}}$ Rich content of organic matter.

${ }^{c}$ Unreliable DT.
}

content of shale is defined as a shale sub-unit of the strata. Mean sonic transit times from all shale sub-units of all wells were plotted against depth. Apparent erosion (displacement on the depth axis from the normal compaction) was determined for each shale sub-unit in each well. Units with shale sub-units were called an average-shale unit and is given a name with an extension A_Sh at the end. For example, quantitative analysis applied to Lower Eocene strata with shale sub-units is named LoEoc_A_Sh. Apparent erosion for averaged-shale unit in each well is determined by the mean of the resultant apparent erosion values of all shale sub-units in the well. The same naming convention was applied to sand sub-units. Units with subdivided sand subunits were called average-sand units and have an extension A_Sa at the end of the unit name. Apparent erosion for averaged-sand unit in each well was determined by the mean of the resultant apparent erosion values of all sand sub-units in the well. True shale intervals in the unit from all wells were grouped together to perform the analysis. Units analyzed with true shale intervals were called 


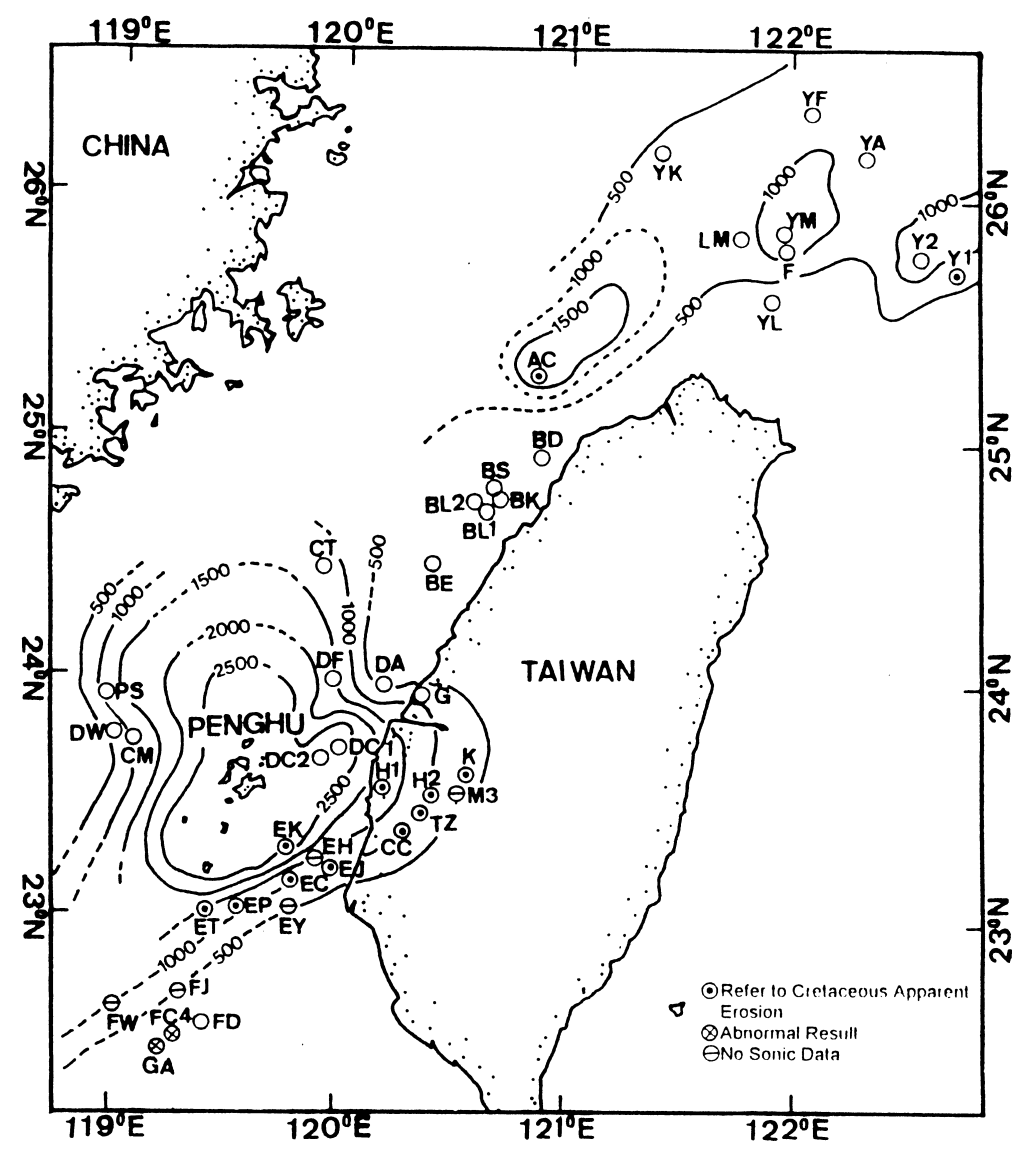

Fig. 6. Apparent erosion map for the mean of averaged-sand and averaged-shale units of Eocene. Apparent erosions on the Penghu Platform and in the Tainan Basin are referred to that resolved from the Cretaceous unit, since Eocene strata are completely missing in these areas.

pure-shale unit and were given a name with an extension P_Sh at the end. Apparent erosion for pure-shale unit in each well was defined as averaged apparent erosion values of all true shale intervals. Apparent erosion was also estimated based on the above selected Neogene units without sub-division. Unit analyzed in this way were called wholestrata-based unit and an extension $S_{-}$added to the beginning of the unit name. To check the validity of data analyzing procedure, apparent erosion values of whole-strata-based unit were used for comparison with those of average-shale units or average-sand units from the same succession in all wells. The resultant magnitudes of erosion for Cenozoic unconformity were delineated as follows.

\section{Result of erosion magnitude for cenozoic unconformity}

\subsection{Mean transit time/depth relations and apparent erosion distribution}

Mean transit-time vs. depth plots of pure-shale, averagedshale, averaged-sand, and whole-strata-based units for the eight selected strata are shown in Fig. 5. Normal compaction lines determined from these units are also shown in this figure. The slope of the normal compaction line shown on the cross-plot basically increases with increasing unit age. Lower Miocene shale has been thought to be a potential rock source in onshore and offshore Taiwan area (Lin, 1991). The points falling below the normal compaction line represent this organic-rich interval. Apparent erosion resolved for all units in all wells are listed in Tables 1-3.

Figs. 6-8 are the apparent erosion maps for the mean of averaged-shale and averaged-sand units of Lower and Middle Eocene strata, the mean of averaged-shale and averaged-sand units of Upper Miocene strata and the mean of averaged-shale and whole-strata-based units of Lower Pliocene strata, respectively. Apparent erosion analyzed from pre-Miocene units (Fig. 6) is mainly distributed at and around the pre-Miocene structural highs. Maximum values of 1500 and $2500 \mathrm{~m}$ were resolved for the Kuanin Uplift at the north and the Penghu Platform at the south, respectively. The magnitudes of apparent erosion from Miocene units (Fig. 7) decrease dramatically on the Penghu Platform compared to that of Pre-Miocene units. Distribution of apparent erosion from Lower Pliocene unit (Fig. 8) is reduced in general compared to that of Lower Miocene, but is in the same order of scale as that of Upper Miocene.

A linear relationship between sonic interval velocity and strata burial depth is assumed in this study. Based on one 


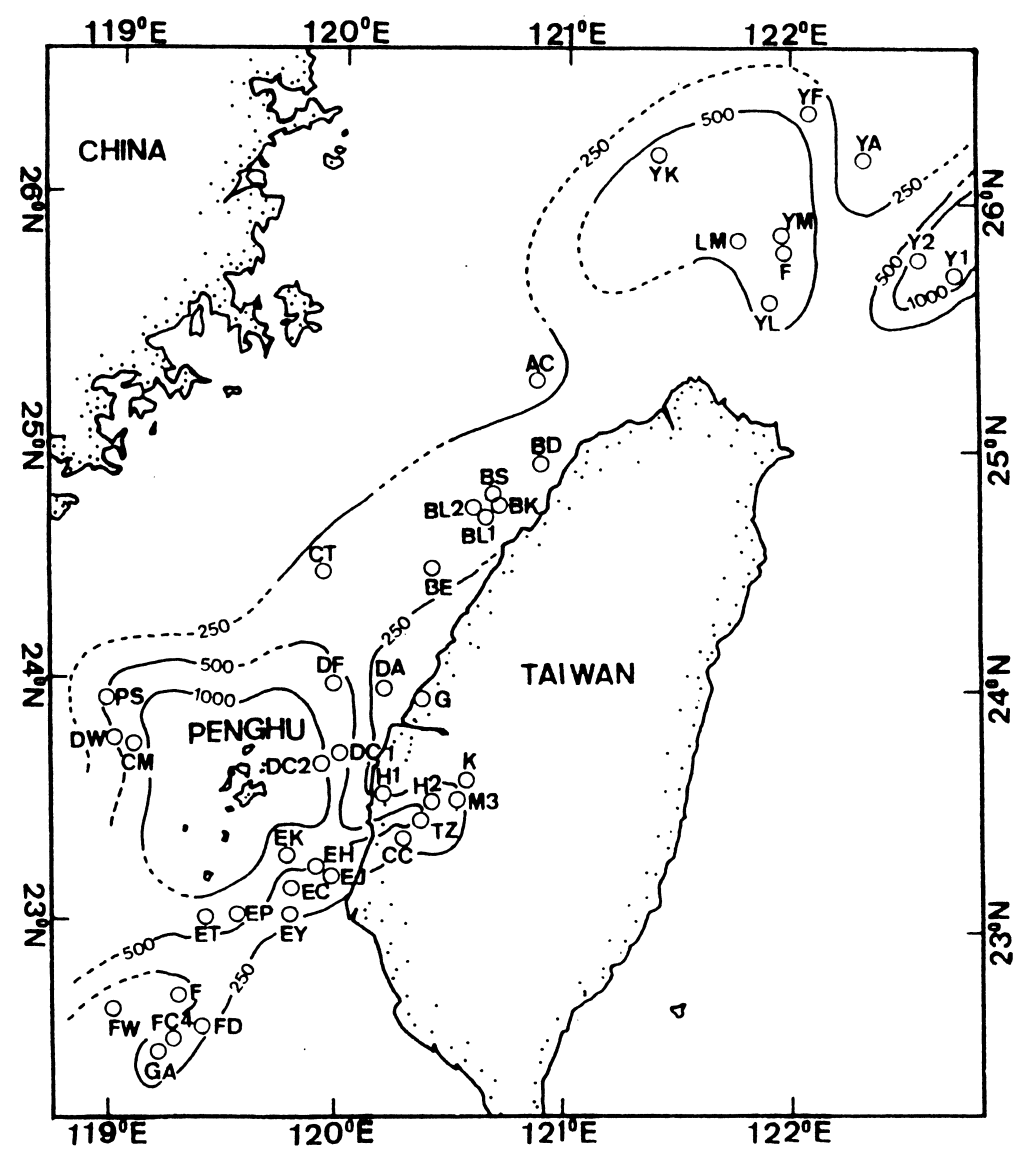

Fig. 7. Apparent erosion map for the mean of averaged-sand and averaged-shale units of Upper Miocene.

million feet sections in 500 Canadian and American wells, Faust et al. (1951) analyzed sonic interval velocity/burial depth relationship for sand and shale with their age ranging from Triassic to Tertiary. A virtually straight line has been observed on the interval velocity/burial depth plot for rocks of Eocene age and younger, yet a curved line has been observed in those older than Eocene and shallower than $4000 \mathrm{ft}$. The assumption applied in this study is believed to be feasible for all except the Cretaceous units. The relationship between logarithm of averaged sonic transit time and mid-point depth of Cretaceous unit are worthy of further investigation to gain a better understanding of the apparent erosion of the Cretaceous.

\subsection{Correlation of apparent erosion values from different units}

Magnitudes of apparent erosion derived from two different units are plotted against each other for correlation analysis. Best-fit, regression linear relationship between the two magnitudes and the associated correlation coefficients are determined based on the data values. Correlation coefficients between apparent erosion resulting from different units are listed in Table 4, along with the number of correlation points. In general, the confidence level of the correla- tion coefficient depends strongly on the number of sample points in the analysis. For the same succession of strata, the resultant apparent erosion from the averaged-shale unit is strongly consistent with that from the averaged-sand unit. Due to the limited number of wells penetrating Cretaceous strata and the absence of Eocene strata on the Penghu Platform including its southeastern area, it is not possible to establish a correlation between Cretaceous and Eocene strata. Apparent erosion values available from Cretaceous unit are combined with those available from Eocene units in order to reconstruct the true erosion map at the Oligocene unconformity. Correlation coefficients between PreMiocene strata and Post-Miocene strata, which are as low as 0.198 , suggest that they do not correlate. This supports the existence of a major Oligocene unconformity between Post- and Pre-Miocene strata, which is not masked in most of the wells by the post Oligocene burial. Except for the Lower Miocene unit, apparent erosion values from other Miocene units and the Lower Pliocene unit appear to be more consistent. This probably is caused by sonic velocity anomalies induced by some rich organic content in the Lower Miocene shale as well as by the onset of hydrocarbon generation. The low correlation coefficient between the Upper Pliocene and the Lower Pliocene is caused by an abrupt increase of sedimentation during the Plio-Pleistocene 


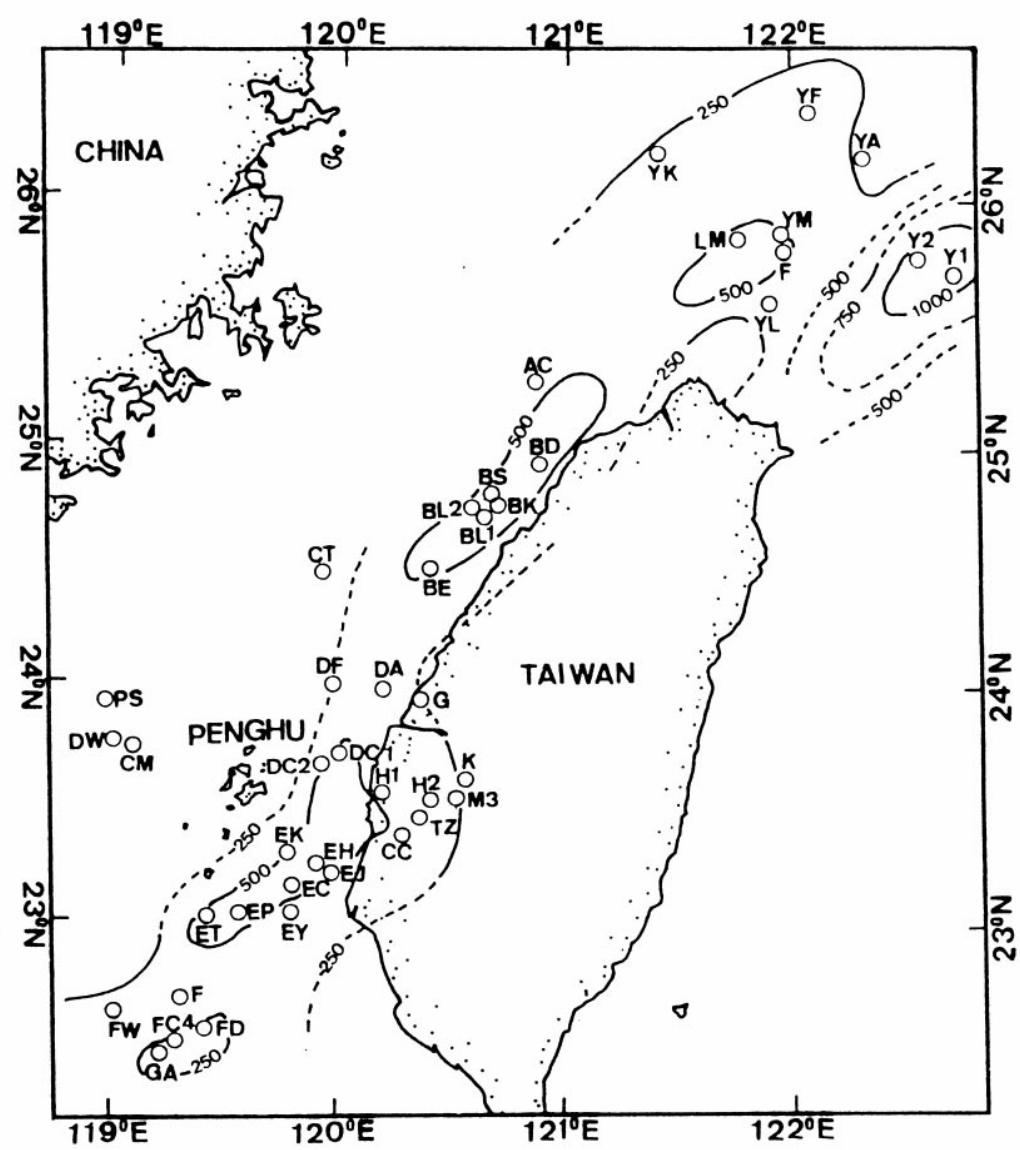

Fig. 8. Apparent erosion map for the mean of averaged-shale and whole-strata-based units of Lower Pliocene.

arc-continent collision and occurrence of a regional Early/ Late Pliocene unconformity nearby the Taiwan-Sinzi folded zone (Hsiao, 1997). The same factors caused the apparent erosion of whole-strata-based unit covered by the Upper Pliocene to be much less consistent with those of Miocene units. Based on this phenomenon, the mean apparent erosion of the Lower Pliocene and the Upper Miocene units is used to reconstruct the true magnitude of the erosion at Plio-Pleistocene unconformity.

The result of the correlation analysis reveals that two distinct exhumation events not masked by post exhumation burial can be identified: Oligocene unconformity and Plio-Pleistocene unconformity. It is justified by similar correlation pattern in Figs. 4 and 9. Units of S_MidMio, S_UpMio and S_UpMio yield similar apparent erosion values. Unit LoEoc_A_Sh exhibits greater apparent exhumation than the three units mentioned above. Unit S_LoPlio exhibits greater apparent exhumation than Unit S_Plei. Unit S_Plei is close to normal compaction and probably exhibits no exhumation for the very small apparent erosion.

Compared to the results of the quantitative analysis using with the whole-strata-based unit, those with averaged-shale unit and averaged-sand units are less influenced by lateral or vertical variation in lithology.

\subsection{True magnitude of erosions and discussions}

\subsubsection{Oligocene unconformity}

After the two unmasked unconformities were identified, the true magnitudes of the erosion were then adjusted for burial depth of each corresponding unconformity. The true magnitude distribution of eroded rocks at the Oligocene unconformity is shown in Fig. 10. They are mainly distributed at and around the two paleo-structural highs, with a maximum erosion of $2500 \mathrm{~m}$ at the Kuanin Uplift and the Pengchiahsu platform in the north, and a maximum erosion of $3500 \mathrm{~m}$ on the Penghu Platform in the south. As indicated in Fig. 10, the true erosion at wells located in the Tainan basin, between the Kuanin Uplift and the Peikang Ridge, and in the Taiwan-Sinzi folded zone, are masked by thick post Miocene burial. Apparent erosion of the Pre-Oligocene units can still be resolved from these wells, but it reflects the apparent erosion at the Plio-Pleistocene unconformity, not the Oligocene unconformity. For each well, any amount less than current burial-depth of the Oligocene unconformity would likely be the true magnitude of erosion at Oligocene unconformity. Interpolating between wells, at which the true magnitude of erosion is not masked, will be one way to estimate the magnitude of true erosion for these wells with huge post-erosion burial. According to the results of 
Table 4

Correlation coefficients between apparent erosion values from different stratigraphic units. (Apparent erosions of all units are listed in Tables 1-3. The number of pair-points in correlation analysis in indicated in the bracket)

\begin{tabular}{|c|c|c|c|c|c|c|c|c|c|c|c|c|}
\hline & C_P_Sh & C_A_Sh & LoEoc_P_Sh & LoEoc_A_Sh & MidEoc_P_Sh & MidEoc_A_Sh & S_LoMio & S_MidMio & S_UpMio & UpMio_A_Sh & UpMio_A_Sa & S_UpPlio \\
\hline C_A_Sh & $0.95(13)$ & & & & & & & & & & & \\
\hline C_A_Sa & & $0.93(12)$ & & & & & & & & & & \\
\hline LoEoc_A_Sh & & & $0.98(9)$ & & & & & & & $0.17(7)$ & & \\
\hline MidEoc_A_Sh & & & & $0.63(4)$ & $0.86(5)$ & & & & & & & \\
\hline MidEoc_A_Sa & & & & & & $0.81(7)$ & & & & & & \\
\hline S_LoMio & & & & & & & & $0.7(26)$ & & & & \\
\hline S_MidMio & & & & & & & & & $0.84(22)$ & $0.84(22)$ & & $0.35(22)$ \\
\hline S_UpMio & & & & & & & $0.59(25)$ & & & & & $0.47(24)$ \\
\hline LoMio_A_Sh & & & & $0.56(10)$ & & & & & & $0.54(20)$ & & \\
\hline LoMio_A_Sa & & & & & & & & & & & $0.63(13)$ & \\
\hline UpPlio_A_Sh & & & & & & & & & & $0.34(8)$ & & \\
\hline LoPlio_A_Sh & & & & $0.19(6)$ & & & & & & $0.7(21)$ & & \\
\hline S_LoPlio & & & & & & & $0.32(30)$ & $0.77(20)$ & $0.8(22)$ & & & $0.7(24)$ \\
\hline
\end{tabular}



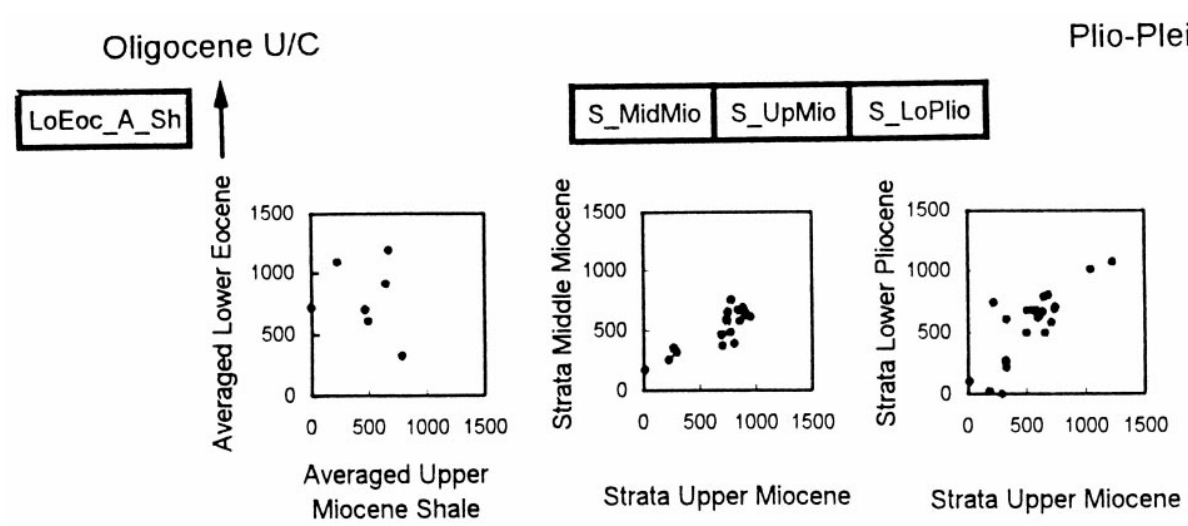

Plio-Pleistocene U/C

Fig. 9. The Oligocene and Plio-Pleistocene unconformities unmasked by post-erosion burial can be identified by low correlation coefficient between apparent erosions from unit above and bellow the unconformity and high correlation coefficient between apparent erosions from units bounded by the unconformities. Unit LoEoc_A_Sh exhibits greater apparent erosion than unit S_UpMio, and unit S_LoPlio exhibits greater apparent erosion than unit S_Plei, which is normally compacted and exhibits theoretically no apparent erosion. The subtle apparent erosion resolved for unit S_Plei may be caused by lateral variation of sand/shale ratio and reflect the deviation of estimated apparent erosion.

the rock maturity analysis (Lin, 1991) and the evolution of the Yichu Fault bounding the west margin of the Tainan Basin (Yang, Ting \& Yuan, 1991), true erosion decreases south-east ward once it crosses the Yichu Fault. Although true erosion is masked in area nearby BD well, the amount of true erosion at the Oligocene unconformity would not be too small since an angular contact of Pre-Miocene strata has been observed at the unconformity. The erosion event occurred in different times for different structural units. For the Penghu Platform and the Peikang-Wangkung

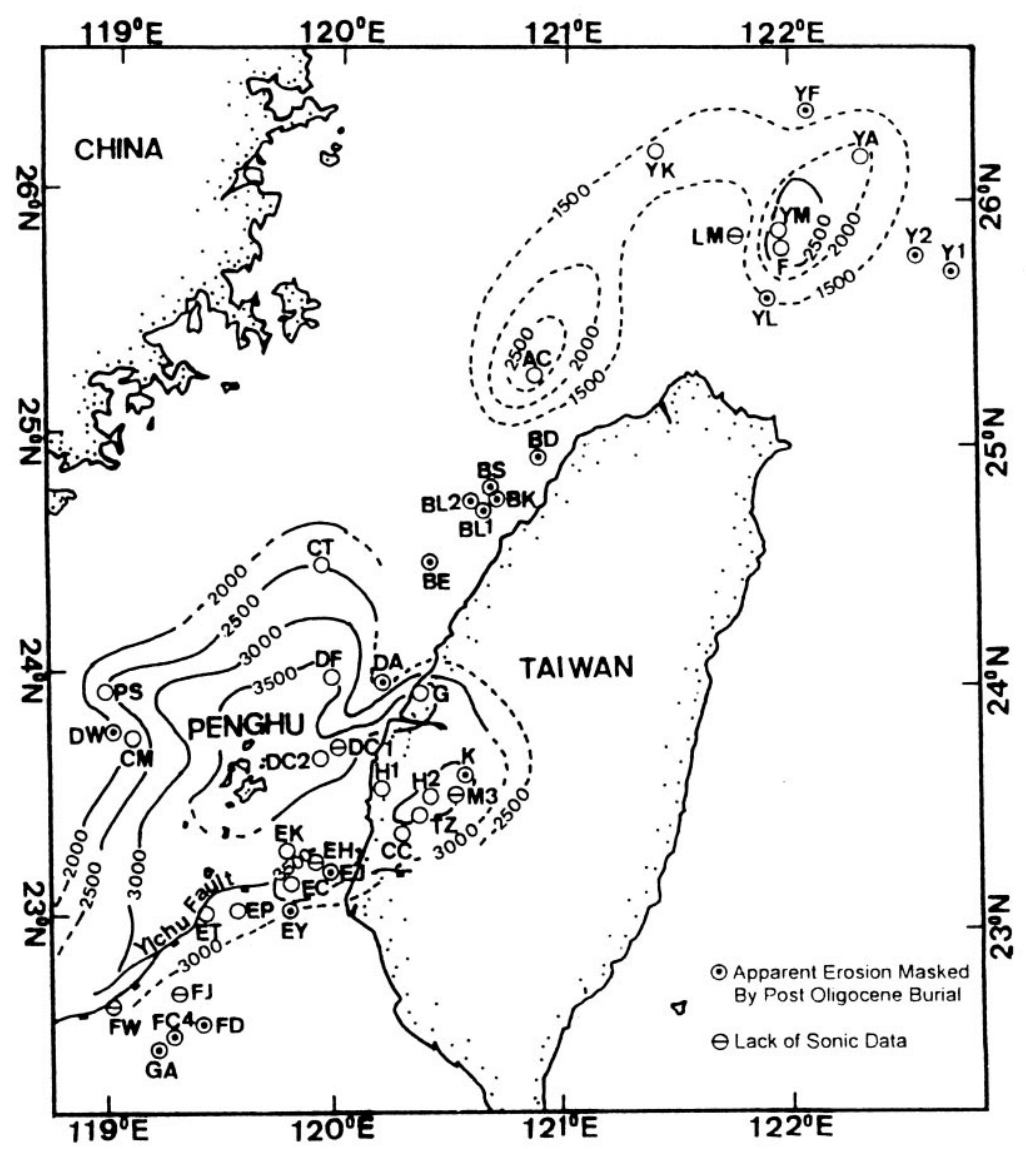

Fig. 10. Distribution of true magnitude of erosion at the Oligocene unconformity with post-erosion burial correction applied. A maximum of $2500 \mathrm{~m}$ was resolved on the Kuanin Uplift and the Pengchiahsu Platform in the north and $3500 \mathrm{~m}$ on the Penghu Platform in the south. 


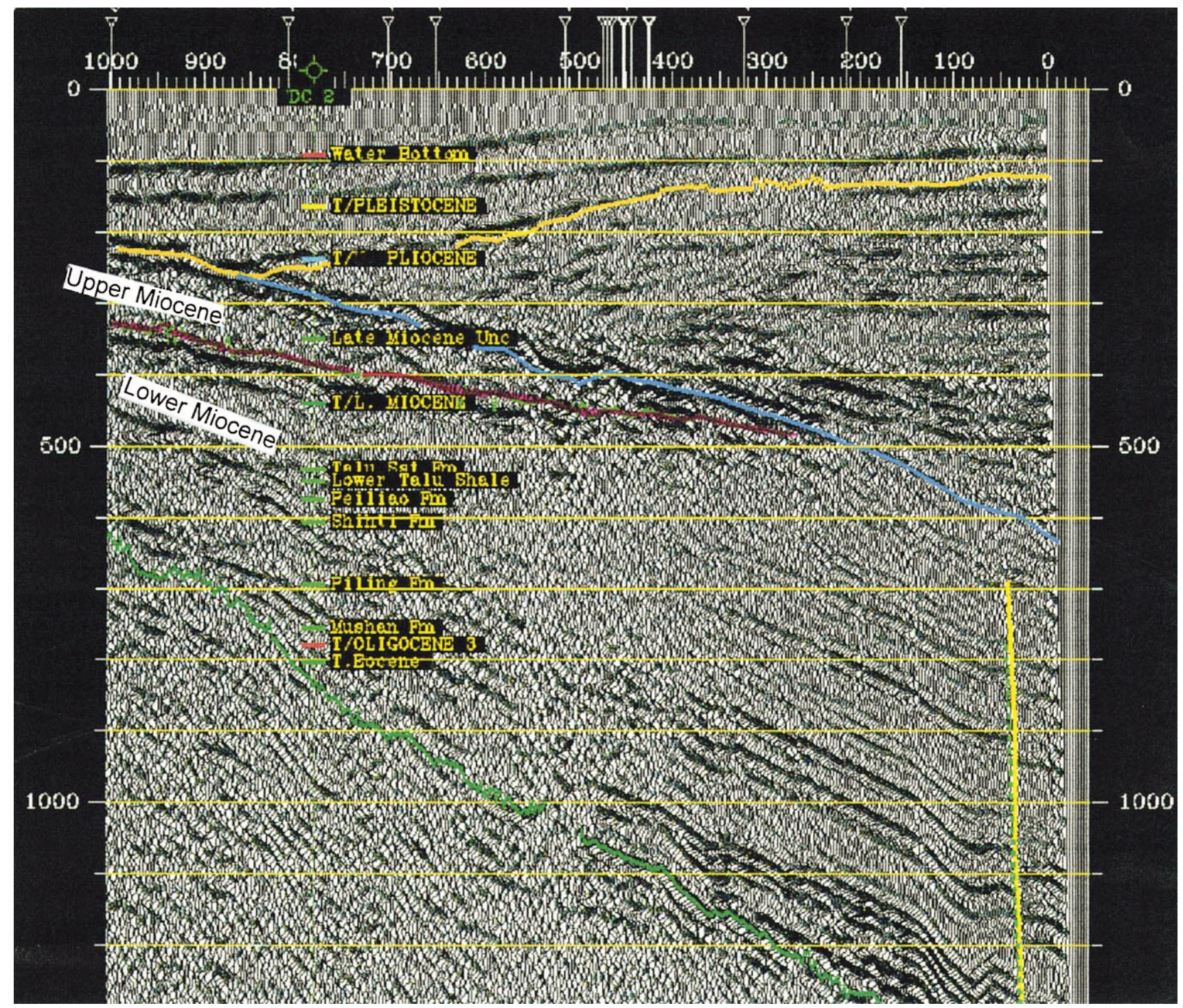

Fig. 11. EW trending seismic profile crossing DC2 well. Miocene strata lay more or less conformably with Pliocene/Upper Miocene unconformity. A strong reflection associated with the red marker on top of Lower Miocene is interpreted as a dike. The yellow marker is interpreted as the base of late Pleistocene Penghu waterway.

Ridge, it was initiated in late Eocene time and ended in the early Miocene. For the Penghu Basin, it took place from the middle Oligocene to the late Oligocene. For the Kuanin Uplift, it commenced in the middle Oligocene and ended in the early Miocene. The early phase of erosion was mainly attributed to uplifting and exposure; whereas the late phase was mainly due to the fall of global sea level during Oligocene. Evidence that the area south of the Penghu Platform and Peikang-Wangkung paleo-Ridge has a maximum erosion of $3500 \mathrm{~m}$ is as follows: (1). Eocene strata are missing in this area; (2). Lower Eocene strata in excess of $2000 \mathrm{~m}$ are present in the DA well located at northwest of the area; and (3). Reworked Eocene nannofossils-microfaunal has been found in the Oligocene lacustrine unit (Fuh \& Wu, 1999) which lies in southern Taishi basin located in the middle part of the study area. Considering the erosion event's time span (approximately $13 \mathrm{Ma}$ ), rock removal occurred at a rate of $0.27 \mathrm{~mm} / \mathrm{yr}$. In the northern part of the Tungintao Ridge and the Pengchiahsu Platform, the true magnitude of erosion for the Oligocene unconformity can be justified by projecting pre-Oligocene strata at the Oligocene unconformity onto the seismic profiles across the wells.

\subsubsection{Miocene unconformity}

The magnitude of true erosion at the Miocene unconformity is regarded as moderate to minor ( 500-1000 m) and the unconformity is overlain by a large amount of posterosion burial. In most of the study area except area nearby the Penghu islands, where the DC2 well is located, the true magnitudes of erosion are masked by post-erosion burial. The observed apparent erosion of over $1000 \mathrm{~m}$ from 


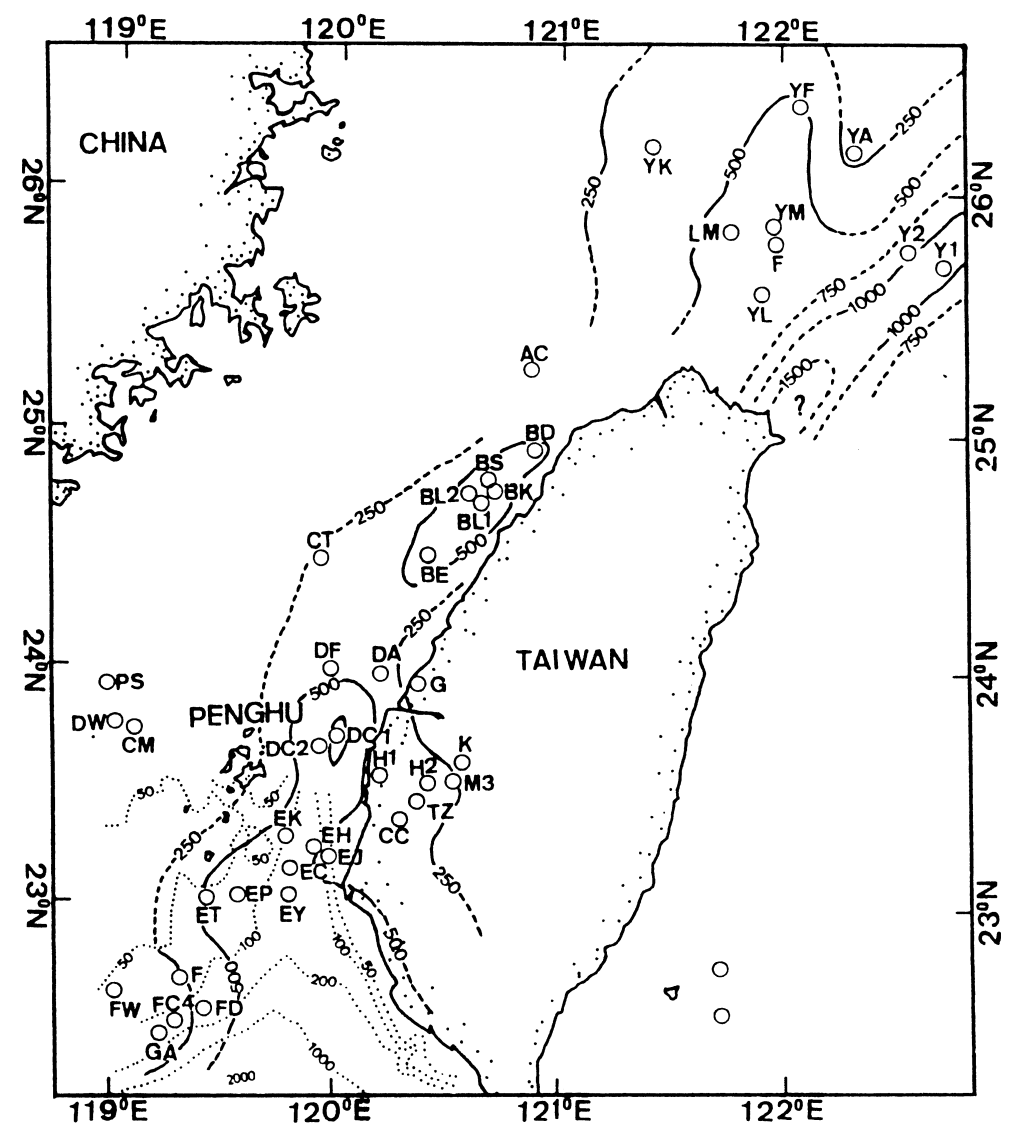

Fig. 12. Distribution of true magnitude of erosion at the Plio-Pleistocene unconformity with post-erosion burial correction applied. A NE trend with a maximum over $1000 \mathrm{~m}$ was resolved for the Taiwan-Sinzi folded zone, where the unconformity was initiated in late Pliocene. Erosion of up to $500 \mathrm{~m}$ on the eastern side of Penghu Island defines the shape of the present day Penghu Waterway (dotted lines).

Miocene units for well DC2 is unusually higher than those of nearby wells. The drilling rate of this well was reduced over certain intervals of the strata analyzed, indicating the possibility of calcareous tight zones. Apparent erosion might have been over-estimated due to the high sonic velocity of the tight zone. The seismic profile trending EW at south of DC2 Well shows that the reflection events underneath Pliocene/Miocene unconformity lay more or less conformably on top of the unconformity (Fig. 11). Previous studies (Angelier, Bergerat \& Chu, 1990; Yen, 1987) suggest that sedimentary rocks might have played a minor role in the composition of Penghu islands. The most western portion of the Penghu islands is composed of porphyrite, while the rest of the island is mainly composed of Late Miocene basalt. These rock components are believed to be extremely resistant to erosion. Given these facts, a magnitude of erosion over $1000 \mathrm{~m}$ is likely to be an over-estimation. The true magnitude of erosion of the nearby Penghu islands may also be masked by post Miocene burial.

\subsubsection{Plio-Pleistocene unconformity}

As mentioned previously, the low correlation coefficients between apparent erosions of upper Pliocene and Miocene are caused by: (1). an abrupt increase in sedimentation rate resulting from the Plio-Pleistocene arc-continent collision; and (2) occurrence of a regional Early/Late Pliocene unconformity in the Taiwan-Sinzi folded zone. On the contrary, compared to the apparent erosion from the upper Miocene shale, the consistency between average apparent erosion from the Lower Pliocene shale is very high. Therefore, the mean of the averaged apparent erosion from upper Pliocene and that from the Upper Miocene was used to construct a true erosion map at the Plio-Pleistocene unconformity. Distribution of the true magnitude of erosion after posterosion correction is shown in Fig. 12.

In the northern part of the study area, a NE trending distribution, with the maximum true erosion of over $1000 \mathrm{~m}$, has been resolved for the Taiwan-Sinzi folded zone. According to Hsiao (1997), a wide spread late/early Pliocene unconformity has been observed in the TaiwanSinzi folded zone, possessing a maximum magnitude in this offshore area near the tip of Taiwan's northeast coast. In this area, Lower Pliocene and most of Miocene strata have been eroded and a high angle contact between the unconformity and the Miocene strata is observed. It is concluded in this study, that the Plio-Pleistocene unconformity initiated in the Taiwan-Sinzi folded zone towards the east around late Pliocene, then proceeded into the Tungyintao Ridge and the 
Kuanin Uplift in the west around early Pleistocene. The absence of upper Pliocene strata at the AC well, located at the Kuanin Uplift, is probably due to non-deposition in late Pliocene considering the low resultant apparent erosion resolved from the Upper Miocene units. Compared to the Tungyintao Ridge, the Kuanin Uplift was geographically relatively higher during the late Pliocene and lower during Pleistocene. Flexural bending, resulting from loading of the thrust wedge during Plio-Pleistocene arc-continent collision, might be an explanation for this phenomenon. Falling of sea level during late/early Pliocene and Pleistocene might be responsible for this erosion event.

In the southern part of the study area, true erosion of up to $500 \mathrm{~m}$ at the Plio-Pleistocene unconformity is mainly distributed on the eastern side of the Penghu Island. The erosion event might have initiated in the late Pleistocene. The distribution configuration is consistent with the layout of the present-day Penghu waterway and may reflect the late Pleistocene Penghu waterway (Fig. 11). The causes of erosion in this area are different from those in the northern area. The cutting by the sub-marine canyon is an important role for the erosion process just as those observed on the shelf and continental slope in southwestern offshore Taiwan areas at the present time (Lee, Hsu \& Tang, 1995; Liu, Lundberg, Reed \& Huang, 1993; Yu \& Chiang, 1997; Yu, Huang \& Ku, 1991).

In the middle of the study area, where the BD, BS, BK4, BL2 and BE wells are located, the locally high true erosion magnitude seems to relate to the Pliocene/Pleistocene folded structures and to sea level fall during Pleistocene. According to Press (1966), external pressure has more influence on seismic velocity traveling through rock media that has been suppressed by a pressure lower than 500 bar. The base of Pliocene in the area reaches a maximum depth of $2000 \mathrm{~m}$ and is suppressed by a lithostatic pressure around 431 bar. The folded strata of Pliocene and Pleistocene suffered lateral compressive forces during arc-continent collision in Taiwan area and this would be reflected in seismic velocity or sonic transit time. Lateral compression can increase pore pressures in the same way as overpressure is caused by vertical stress through inequilibrium compaction, especially for folded strata without fractures (Osborne \& Swarbrick, 1997). Sonic transit times for the folded strata in this area are thus lower than normal, and the apparent erosion resolved would be thus under-estimated. Therefore, the magnitude of true erosion in this area is concluded to be over $500 \mathrm{~m}$. A magnitude as great as this seems to be suspicious; and examination of the seismic profiles across the wells may provide more information. Further investigation on calcification of shale or sand analyzed in the study would also be necessary.

\section{Conclusion}

With the assumption of a linear relationship between sonic interval velocity and burial depth, the distribution of apparent erosion from eight Cenozoic stratigraphic units in forty-four wells were analyzed in offshore Taiwan area. Apparent erosion from Pre-Miocene units is mainly distributed at and around the Pre-Miocene structural highs. Maximum erosion of $1500 \mathrm{~m}$ and maximum of $2500 \mathrm{~m}$ were resolved on the Kuanin uplift in the north and on the Penghu platform in the south, respectively. Compared to pre-Miocene units, the averaged apparent erosion of 500-1000 $\mathrm{m}$ from Pliocene and Miocene units is much more moderate.

Two unmasked unconformities were identified through correlation analysis: the Oligocene and the Plio-Pleistocene unconformities. Low correlation coefficients observed between apparent erosion values from Pre-Miocene strata and from Post-Miocene strata supports the existence of a major Oligocene unconformity, which is not masked in most of the study area by the huge amount of post-Oligocene burial. Except for Lower Miocene unit, apparent erosion from other Miocene units and the Lower Pliocene units is more consistently correlated with each other. Therefore, the mean of apparent erosions from the Lower Pliocene and Upper Miocene units was used to reconstruct the true magnitude of eroded rocks for the Plio-Pleistocene unconformity.

The averaged true erosion at the Oligocene unconformity is mainly distributed at and around the paleo-structural highs. The maximum true erosion at this unconformity is $3500 \mathrm{~m}$ on the Penghu Platform. Approximately $2500 \mathrm{~m}$ of true erosion occurred on the Kuanin uplift and the Pengchiahsu platform. Due to moderate-to-minor erosion and a great amount of post-erosion burial, true erosion at the Miocene unconformity is masked in most of the study area. Erosion of up to $500 \mathrm{~m}$ on the eastern side of Penghu Island at the Pleistocene unconformity defines the shape of the present day Penghu Waterway. In the northern offshore area up to $1000 \mathrm{~m}$ of Plio/Pleistocene true erosion occurred in the Taiwan-Sinzi folded zone where Miocene folds are observed. The magnitude of true erosion decreased west of the Taiwan-Sinzi folded zone to be $500 \mathrm{~m}$ in the Pengchiahsu Basin. A maximum of $500 \mathrm{~m}$ of true erosion is also observed in the west offshore area along Hsing-Chu to the Miaoli coast.

\section{Acknowledgements}

The author would like to thank T.Y. Chang for his efforts in directing the application of commercial software used in this study. The author also thanks C. H. Fan, Mike Fu and Philippe Schnurle for reviewing the manuscript and the Chinese Cooperation for the permission to publish this paper.

\section{References}

Angelier, J., Bergerat, F., \& Chu, H. T. (1990). Paleostress analysis as a key to margin extension: The Penghu Islands, South China Sea. Tectonophysics, 183, 161-176. 
Dow, W. G. (1977). Kerogen studies and geological interpretation. Journal of Geochemical Exploration, 7, 79-99.

Faust, L. Y. (1951). Seismic velocity as a function of depth and geologic time. Geophysics, 16, 192-206.

Fuh, S. C., Wu, J. C. (1999). Evolution of the faulting in the southern Taihsi basin since early Tertiary and its insight into the conflict of biostratigraphical dating. Annual Meeting of Geological Society of China, Taipei (pp. 70-72).

Hillis, R. R. (1991). Chalk porosity and Tertiary uplift, Western Approaches Trough, SW UK and NW French continental shelves. Journal of the Geological Society of London, 148, 669-679.

Hillis, R. R. (1993). Tertiary erosion magnitudes in the East Midlands Shelf, onshore UK. Journal of the Geological Society of London, 150, $1047-1050$.

Hillis, R. R. (1995). Regional Tertiary exhumation in and around the United Kingdom. In J. G. Buchanan \& P. G. Buchanan, Basin inversion, Geological Society of London Special Publication, 88 (pp. 167-190). London: Geological Society.

Hillis, R. R., Thomson, K., \& Underhill, J. R. (1994). Quantification of Tertiary erosion in the Inner Moray Firth using sonic velocity data from the Chalk and the Kimmeridge Clay. Marine and Petroleum Geology, 11, 283-293.

Hsiao, L. Y. (1997). Geological structure of late Cenozoic in the northeastern offshore area of Taiwan. Master thesis, Oceanography Institute, National Taiwan University, Taipei (p. 62).

Hu, C. C., Chou, T. H., Yuan, C. W., Lin, K. A., Chi, W. R. (1981). The hydrocarbon exploration study of geology and geochemistry in Peikang area, Taiwan. Special Report of Research and Development Project of Economic Ministry, Taiwan (pp. 14-29).

Huang, C. Y., \& Yin, Y. C. (1990). Bathymetric ridges and trough in the active arc-continent collision region offshore Taiwan. Proceedings Geological Society of China, 33, 351-372.

Huang, C. Y., Shyu, C. T., Lin, S. B., Lee, T. Q., \& Sheu, D. D. (1992). Marine geology in the arc-continent collision zone off southwestern Taiwan: implication for late Neogene evolution of the Coastal Range. Marine Geology, 107, 183-212.

Issler, D. R. (1992). A new approach to shale compaction and stratigraphic restoration, Beaufort-Mackenzie, Basin and Mackenzie Corridor, northern Canada. American Association of Petroleum Geologists Bulletin, 76, 1170-1189.

Japsen, P. (1998). Regional velocity-depth anomalies, North Sea Chalk: A record of overpressure and Neogene uplift and erosion. American Association of Petroleum Geologists Bulletin, 82, 2031-2074.

Katz, B. J., Pheifar, R. N., \& Schunk, D. J. (1988). Interpretation of discontinuous vitrinite reflectance profiles. American Association of Petroleum Geologists Bulletin, 72, 926-931.

Lee, C. S., Shor, G. G., Bibee, L. D., Lu, R. S., \& Hilde, T. (1980). Okinawa Trough: origin of a back-arc basin. Marine Geology, 35, 219-241.

Lee, T. Y., Tang, C. H., \& Ting, J. S. (1993). Sequence Stratigraphy of the Tainan basin, offshore southern Taiwan. Petroleum Geology of Taiwan, 28, 119-158.

Lee, T. Y., Hsu, Y. Y., Tang, C. H. (1995). Structural geology of the deformed front between $22^{\circ} \mathrm{N}$ and $23^{\circ} \mathrm{N}$ and migration of the Penhu canyon, offshore southwestern Taiwan arc-continent collision zone. International Conference and 3rd SINO-French Symposium Active Collision in Taiwan, March 22-23 (pp. 219-227).
Letouzey, J., \& Kimura, M. (1985). Okinawa Trough genesis: structure and evolution of a back-arc basin developed in a continent. Marine and Petroleum Geology, 2, 111-130.

Lin, L. H. (1991). Geochemical study of Tainan basin. Annual Report of Exploration and Development Research of Chinese Petroleum, 14, 128-146 (in Chinese).

Liu, C. S., Lundberg, N., Reed, D., \& Huang, Y. S. (1993). Morphological and seismic characteristics of the Kaoping Submarine Canyon. Marine Geology, 111, 93-108.

Liu, C. S., Huang, I. L., \& Teng, L. S. (1997). Structure off southwestern Taiwan. Marine Geology, 137, 305-319.

Lu, C. Y., \& Hsu, K. J. (1992). Tectonic evolution of the Taiwan mountain belt. Petroleum Geology of Taiwan, 27, 21-45.

Magara, K. (1976). Thickness of removed sedimentary rocks, paleoporepressure and paleotemperature, southwestern part of Western Canada Basin. American Association of Petroleum Geologists Bulletin, 60, 554-565.

Menpes, R. J. (1997). Tertiary uplift and its implications for the tectonic evolution of sedimentary basin, offshore south-west United Kingdom. Unpublished $\mathrm{PhD}$ thesis, University of Adelaide.

Menpes, R. J., \& Hillis, R. R. (1995). Quantification of Tertiary exhumation from sonic velocity data, Celtic Sea/south-western approaches. In J. G. Buchanan \& P. G. Buchanan, Basin inversion, Geological Society of London Special Publication, 88 (pp. 191-207). London: Geological Society.

Osborne, M. J., \& Swarbrick, R. E. (1997). Mechanisms for generating overpressure in sedimentary basins: a reevaluation. American Association of Petroleum Geologists Bulletin, 81, 1023-1041.

Press, F. (1966). Seismic velocities. In S. P. Clark, Handbook of physical constant (pp. 195-218). Geophysical Society of America, Incorporated.

Sun, S. C. (1982). The Tertiary basin of offshore Taiwan. Proceedings of the Second ASCOPE Conference and Exhibition, Manila, Philippines (pp. 126-135).

Sun, S. C. (1985). The Cenozonic tectonic evolution of offshore Taiwan. Energy, 10, 421-432.

Suppe, J. (1984). Kinematics of arc-continent collision, flipping of subduction, and back-arc spreading near Taiwan. Memoir Geological Society of China, 6, 21-33.

Teng, L. (1990). Geotectonic evolution of late Cenozioc arc-continent collision in Taiwan. Tectonophysics, 183, 57-76.

Waples, D. W. (1994). Modeling of sedimentary basins and petroleum systems. In L. B. Magoon \& W. G. Dow, The petroleum systems from source to trap. American Association of Petroleum Geologists Memoir (pp. 307-322).

Yang, K. M., Ting, H. H., \& Yuan, J. (1991). Structural style and tectonics modes of Neogene extensional tectonics in southwestern Taiwan: implications for hydrocarbon exploration. Petroleum Geology of Taiwan, 26, $1-31$.

Yen, T. P. (1987). Geology of the Penghu Islands. Taiwan Bulletin of Geophysics, National Central University, Chungli (Taiwan), 27-28, $1-43$.

Yu, H. S., \& Chiang, C. S. (1997). Kaoping shelf: morphology and tectonic significance. Asian Earth Science, 15, 9-18.

Yu, H. S., Huang, C. S., \& Ku, J. W. (1991). Morphology and possible origin of the Kaoping submarine canyon head off southwest Taiwan. Acta Oceanographica Taiwanica, 27, 40-50. 